\title{
ERRATA
}

No artigo "Genotypic characterization of ten microsatellite loci in two Brazilian free range (Caipira) chicken lines" publicado no periódico Ciência Rural na idenditificação dos autores onde se lia:

\section{"Fábio Pértile}

leia-se:

"Fábio Pértille"III"

Para a versão correta, acesse:

http://www.scielo.br/pdf/cr/2015nahead/1678-4596-cr-0103_8478cr20140132.pdf 